\title{
The Influence of the Phytosanitary Treatments Applied During Vegetation Period, on the Decay of the Stored Apples
}

\author{
Radu Alexandru GROZA ${ }^{1}$, Carmen Emilia PUIA ${ }^{1 *}$ \\ ${ }^{1}$ Faculty of Agriculture, Department of Environmental and Plant Protection, University of Agricultural \\ Sciences and Veterinary Medicine, Manastur Street, No. 3-5, 400372, Cluj-Napoca, Romania, \\ * corresponding author: carmen.puia@yahoo.com \\ Bulletin USAMV series Agriculture 72(1)/2015 \\ Print ISSN 1843-5246; Electronic ISSN 1843-5386 \\ DOI 10.15835/buasvmcn-agr: 11192
}

\begin{abstract}
The overall quality and condition of fresh products cannot be improved after harvest, so a good crop husbandry is important in achieving good yields and quality. During storage there are three types of pathogens which occur: pathogens that infect and occur in vegetation and deposits, pathogens that infect in vegetation and occur only in storage and pathogens which infect and occur in storage. In this study we tried to determine if the treatments applied in the vegetation period influence in some way the quality and the decay of stored apples. In general, apples are affected by a high number of pathogens that produce qualitative decay during storage and this might be reduced by a good husbandry during vegetation and by decreasing the number of pathogens transported from field to storage.
\end{abstract}

Keywords: decay, harvest, pathogen, phytosanitary.

\section{INTRODUCTION}

Apples are produced commercially in the most countries from the temperate region of the world and also in some tropical areas with high altitude (Ferree and Warrington, 2003). The overall quality and condition of fresh products cannot be improved after harvest, so a good crop husbandry is important in achieving good yields and quality. All living material is subject to attack by parasites, so apples can become infected by pathogens before or after the harvest. Some pathogens are able to penetrate the unbroken skin of products and others require an injury in order to cause infection. These damages are probably the major cause for the loss of fresh products (Pastor and Straus, 2010). During storage there are three types of pathogens which occur: pathogens that infect and occur in vegetation and deposits, pathogens that infect in vegetation and occur only in storage and pathogens which infect and occur in storage.

\section{AIMS AND OBJECTIVES}

The aim of this study was to determine if the treatments applied in the vegetation period influence in some way the quality and the decay of stored apples.

\section{MATERIALS AND METHODS}

The experimental plot and the warehouse were located in Zalau, Salaj County, Romania. For the research we've used five cultivars of apple: Granny Smith, Topaz, Gala Imperial, Jonagold and Golden Reinders. For the phytosanitary treatments we've used three treatment plans for the control of powdery mildew and scab: Funguran $\mathrm{OH} 50$ WP + Kumulus DF (T1), Cuproxat Flowable + Kumulus DF (T2) and the product Topsin 70 WDG (T3). In the same time we had an untreated plot. The metal copper was used in two forms: copper hydroxide and tribasic copper sulfate. The storage experiment covered two years $(2012-2014)$ in 
Tab. 1. The influence of the phytosanitary treatments applied during vegetation period, on the decay of the stored apples (2012-2013)

\begin{tabular}{|c|c|c|c|c|}
\hline Test variant & $\begin{array}{c}\text { Degree of atack } \\
\%\end{array}$ & $\%$ to control & $\begin{array}{c}\text { The difference } \\
\text { to control }\end{array}$ & $\begin{array}{c}\text { The significance of } \\
\text { the difference }\end{array}$ \\
\hline No treatment & 21.32 & 100.0 & 0.00 & Mt. \\
\hline $\mathrm{T} 1$ & 12.77 & 59.9 & -8.55 & 000 \\
\hline $\mathrm{T} 2$ & 12.86 & 60.3 & -8.46 & 000 \\
\hline $\mathrm{T} 3$ & 11.20 & 52.5 & -10.12 & 000 \\
\hline LSD (p 5\%) 0.50 & LSD (p 1\%) 0.66 & LSD (p0.1\%) 0.86 & & \\
\hline
\end{tabular}

Tab. 2. The behavior of some apple cultivars during storage

\begin{tabular}{ccccc}
\hline Variant & $\begin{array}{c}\text { Degree of atack } \\
\%\end{array}$ & $\begin{array}{c}\% \text { to } \\
\text { control }\end{array}$ & $\begin{array}{c}\text { The difference } \\
\text { to control }\end{array}$ & $\begin{array}{c}\text { The significance of } \\
\text { the difference }\end{array}$ \\
\hline Variant average & 14.54 & 100.0 & 0.00 & Mt. \\
\hline Granny Smith & 12.10 & 83.2 & -2.44 & 000 \\
\hline Topaz & 5.19 & 35.7 & -9.35 & 000 \\
\hline Gala Imperial & 31.71 & 218.2 & 17.18 & 000 \\
\hline Jonagold & 8.64 & 59.4 & -5.90 & - \\
\hline Golden Reinders & 15.05 & 103.5 & 0.51 & 1.72 \\
\hline LSD (p 5\%) & 0.91 & LSD (p 1\%) & 1.25 & LSD (p 0.1\%) \\
\hline
\end{tabular}

natural conditions, from September to February. Twice a month we've made observations on the phytosanitary status of the stored apples about the frequency of the decay (F\%), the intensity of the decay (I\%) and the degree of the decay (DD\%), (Carmen Puia et al., 2003).

\section{RESULTS AND DISCUSSIONS}

Climatic conditions during growing period did not significantly influence the fungal load responsible for the decay of fruit during storage. The application of phytosanitary treatments according to warns received from the National Phytosanitary Agency led to storing fruits with no obvious symptoms of disease. The average degree of attack, at the varieties studied in this two experimental years, during storage, did not have significant differences from one year to another.

Treatments applied during growing season significantly influenced the occurrence and manifestation of decay symptom during storage. As can be seen in Tab. 1, at all variants where we applied treatments with plant protection products, the average degree of attack was reduced, the differences compared to the control, to which was not applied any treatment, were highly significant negative.

The cultivars studied behaved differently during storage period. The most susceptible cultivar to decay symptom was Gala Imperial, the difference between the average degree of attack for this cultivar and the average degree of attack for the control variant, was very significantly positive. The most resistant cultivar for the pathogens attack during storage period was Topaz that had the lowest level of decay $5.19 \%$ (tab. 2). Other research on apples decay during storage time was performed by Carmen Puia et al., (2003).

\section{CONCLUSION}

In general, apples are affected by a high number of pathogens that produce qualitative decay during storage and this might be reduced by a good husbandry during vegetation and by decreasing the number of pathogens transported from field to storage.

\section{REFERENCES}

1. Ferree DC, Warrington IJ (2003). Apples: botany, production and uses. CABI Publishing. ISBN 0-85199592-6.

2. Pastor SS, Straus MC (2010). Post-harvest Technology of Horticultural Crops. Oxford Book Company. ISBN 978-9380179-25-4.

3. Puia C, Popovici E, Florian V (2003). The evolution of the phytosanitary status of the stored apples in natural conditions. JOURNAL 4(4):319-325. 